\title{
Karykatura jako narzędzie polityki państwa
}

Karykatura jest jedną z form ekspresji artystycznej. Bardzo specyficzną, gdyż cele jej wyraźnie różnią się od tych, które stawiają sobie twórcy obrazów, chcący odmalować osobę, krajobraz, oddać piękno przyrody czy architektury. Karykaturzysta stawia sobie inne zadanie. Podobnie jak satyryk, chce zakpić z jakiejś osoby, grupy osób, wyśmiać czyjeś ułomności, wady, przejaskrawić cechy wyglądu. Karykatura ma z jednej strony bawić, z drugiej przerażać, ale także „oswajać" rzeczywistość. Karykaturzysta deformuje rzeczywistość po to, aby zabawić odbiorcę ${ }^{1}$. Karykatura pozwalająca z samego założenia na deformacje i przejaskrawienia, daje twórcy znaczną swobodę artystyczną. Realizowana jest głównie w rysunku bądź grafice². Definiując karykaturę, wskazuje się niekiedy, że jest ona „syntezą uwidocznionego wyrazu oraz charakteru istoty żyjącej lub przedmiotu, wyrażoną plastycznie w sposób prosty, dosadny, oryginalny i dowcipny, a przede wszystkim jaskrawy i frapujący wyobraźnię․ Zauważa się, że słowo karykatura pochodzi od włoskiego caricare tj. przesadzać, przejaskrawiać4. W literaturze anglo-amerykańskiej termin cartoon, oznaczający rysunek satyryczny bądź film rysunkowy, jest składnikiem pictorial communication i pozostaje w opozycji do

${ }^{1}$ Wskazuje się w literaturze, że karykatura wyróżnia się dynamizmem kreacji, dostępnością percepcji, co powoduje, że przekazy te rozpowszechniają się powszechnie i szybko, a ich percepcja nie wymaga specjalnego przygotowania, a nawet znajomości języka Zob. Г. Гайлите, Медведь и Латвия: образы латышско - российских отношений в карикатуре, «Лабиринт. Журнал социально-гуманитарных исследований», 2013, № 4, s. 29; М.Б. Ворошилова, Мультипликаичинные герои в современной политической карикатуре, «Человек в мире культуры” 2013, № 1, s. 37.

${ }^{2}$ Г. Гайлите, ibidem.

3 Jotes [Jerzy Szwajcer], Okiem karykaturzysty, Warszawa 1926, s. 3.

${ }^{4}$ Wielka Ilustrowana Encyklopedia Powszechna, t. VII, Kraków 1995, s. 201. 
określenia caricature, który oznacza rysunek wyolbrzymiający lub pomniejszający niektóre osoby lub rzeczy ${ }^{5}$.

Karykatury pojawiły się już w głębokiej starożytności, istniały w średniowieczu i gwałtownie rozwinęły się po wynalezieniu druku. Wymagały od parających się tą formą artystyczną znacznej sprawności warsztatowej, posłużenia się skrótem, wyczucia gustów odbiorcy, zjadliwości obserwacyjnej. Nie da się zaprzeczyć, że długi czas karykatura miała przede wszystkim charakter personalny - uderzała w określone osoby, szydząc $\mathrm{z}$ wad ich charakteru, a zwłaszcza przerysowując wygląd. Z biegiem czasu karykatura zmieniła swój charakter. Nastąpiło to w okresie reformacji i późniejszych wojen religijnych. Tu karykaturzyści chcieli zohydzić przeciwnika ideologicznego, wyśmiać jego światopogląd, zakpić z wyznawanych przekonań religijnych. Ostrze satyry godziło więc, pozornie, w jednostki: papieża, Lutra czy Kalwina, tak jak to miało miejsce wcześniej, ale w gruncie rzeczy chodziło nie o te osoby, lecz o wartości, którym one hołdowały ${ }^{6}$.

Jak zauważa się w literaturze, gwałtowny rozwój karykatur nastąił w końcu XVIII w. i trwa po dzień dzisiejszy. Przy czym, jak się wydaje, rozwój techniki i upowszechnienie przekazu internetowego doprowadziły do powstania nowych form karykatur - memów ${ }^{7}$

${ }^{5}$ W. Głodkowski, Karykatura polityczna jako forma komunikowania w badaniach amerykańskich, „Zeszyty Prasoznawcze”, R. XXIX, 1988, nr 3, s. 29 i n.

${ }^{6}$ J. F. Champfleury, Histoire de la caricature antique, wyd. 2, Наchette 2013; И. В. Чепуров, Изобразительные средства отечественной карикатуры XVII-XX веков, „Вестник ОГУ”, 2014, nr 5 (166), s. 142-148; L. Baridon, M. Guédron, L'Art et l'histoire de la caricature: Des origines à nos jours, Paris 2006.

7 Wbrew powszechnemu przekonaniu, mem nie jest zjawiskiem ostatnich lat, a nawet dziesięcioleci. Termin meme został użyty przez R. Dawkinsa (właśc. Clintona Richarda Dawkinsa), brytyjskiego zoologa, etologa ewolucjonisty i publicysty, profesora Uniwersytetu Oxfordskiego w książce „Samolubny gen” (wyd. 1976, wyd. polskie Warszawa 1996), będącej popularno-naukowym przedstawieniem zagadnienia ewolucji. W pracy tej R. Dawkins zdefiniował mem jako replikator, a więc samopowielającą się strukturę dążącą do osiągnięcia jak największej liczby własnych kopii. W biologii replikatorami są geny, natomiast w świecie kultury analogicznie do genów - memy. Słowo mem pochodzi od greckiego terminu mimesis, czyli naśladownictwo. W języku angielskim pochodną terminu greckiego meimesis, za pośrednictwem łacińskiego określenia memento (pamiętaj) jest memory (pamięć), w języku francuskim merne (taki sam). Terminu mem nie zna jednak ani Stownik języka polskiego (red. M. Skorupka, wyd. 1988), ani Uniwersalny stownik języka polskiego (red. S. Dubisza, wyd. 2003). Nie występuje on także w pochodzących z tego okresu kolejnych wydaniach Stownika wyrazów obcych PWN, ani też w Wielkiej Encyklopedii PWN (Warszawa 2003). We współczesnej internetowej wersji Encyklopedii PWN istnieje już, oczywiście, hasło mem oraz memetyka na oznaczenie metody badania kultury i społeczeństwa na podstawie koncepcji memów (https://encyklopedia.pwn.pl/haslo/mem;3939564.html). Definicję memu zaprezentowano również w internetowej wersji Słownika języka polskiego PWN, wyjaśniając ten termin jako „chwytliwą porcję informacji, zwykle w formie krótkiego filmu, obrazka lub zdjęcia, na którym umieszczono jakiś tekst, rozpowszechniana w Internecie", czyli odmiennie od Encyklopedii i inaczej, niż to chciał rozumieć R. Dawkins. Dopiero w 2016 r. w Wielkim słowniku ortograficznym PWN pojawia się termin mem. 
internetowych ${ }^{8}$. Memy najczęściej stanowią formę komentarza do bieżących wydarzeń. Służą ocenie aktualnej sytuacji społeczno-politycznej, mogą wywoływać dyskusję na dany temat lub być jej argumentem 9 . Mogą opisywać rzeczywistość jednocześnie diagnozując jej aktualne problemy. Memy stały się nową formą wyrażania swoich poglądów oraz oceny danej sytuacji ${ }^{10}$. $Z$ uwagi na to, że zwykle związane są z danym wydarzeniem lub sytuacją bardzo łatwo się dezaktualizują. Często bez podanego kontekstu, np. tytułu, daty lub opisu sytuacji, stają się ciężkie do zrozumienia lub po prostu nieczytelne ${ }^{11}$. Ta ostatnia cecha łączy je z „klasyczną" karykaturą.

Karykatury z okresu Wielkiej Rewolucji Francuskiej oraz późniejsze z czasów wojen napoleońskich, zarówno publikowane we Francji, jak i w Wielkiej Brytanii oraz w Rosji, miały jeszcze wiele wspólnego z wcześniejszymi przekazami tego typu. Przedmiotem ataku była osoba przywódcy przeciwnika w czasach Rewolucji - Ludwika XVI, potem Napoleona. Poprzez postać przywódcy wykrzywiany jest obraz przeciwnika. Chociaż bywało z tym różnie, czego dowodzą chociażby karykatury Aleksandra Orłowskiego ${ }^{12}$, ukazującego w alegorycznej formie wrogie działania Francji i państw niemieckich przeciwko Rosji. Ta ostatnia przedstawiona jest $\mathrm{w}$ postaci niedźwiedzia, będącego obiektem ataków orła i wron. W literaturze rosyjskiej wskazuje się, że rysunek ten obnaża rzeczywistość społeczną w Rosji i nędzę narodu, co uosabiać ma postać rozzutego, leżącego twarzą do ziemi chłopa - na drugim planie. Niedźwiedź stojący na tylnych łapach,

\footnotetext{
${ }^{8}$ Mem internetowy to, jak stwierdza Agnieszka Niekrewicz, „kompleks znaków werbalnych i wizualnych, przekazywany i modyfikowany za pośrednictwem sieci”. Zob. A. A. Niekrewicz, Stowo a obraz. Memetyczne sposoby wyrażania pogladów społeczno-politycznych, w: D. Bizior, D. Suska (red.), „Mechanizmy ekonomizacji języka”, Tom IV, Częstochowa 2014, s. 12. Eadem, Środki językowo-obrazowe stużace etykietowaniu polityków w memach internetowych, „Poznańskie Studia Polonistyczne. Seria Językoznawcza” vol. 23 (43), nr 1/2016, s. 55. Nieco inaczej termin mem rozumie Jakub Nowak, uważający, że jest to pewien typ treści medialnej, który szybko zyskuje popularność wśród osób korzystających z Internetu, najczęściej poprzez spontaniczne przekazywanie jej pomiędzy użytkownikami sieci. Zob. J. Nowak, Memy internetowe: teksty (cyfrowej) kultury językiem krytyki społecznej, w: I. Hofman, D. Kępa-Figura (red.), „Współczesne Media. Język Mediów", Lublin 2013, s 239. Podobną definicję zakłada: P. Bałdys, Memy, mashupy, viral videos - opisywanie rzeczywistości społecznej w czasach kultury digitalnej, „Studia Medioznawcze” $\mathrm{nr}$ 5/2015, s. 107; L. Shifman, Memes in a Digital World: Reconciling with a Conceptual Troublemaker, „Journal of Computer-Mediated Communication”, nr 18/2013, s, 364-365. Obie definicje zakładają, że aby dana informacja mogła być memem internetowym, konieczna jest jej popularność wśród internautów, zasadzająca się na ich wzajemnym przekazywaniu.

${ }^{9}$ A. Niekrewicz, Środki językowo-obrazowe, op.cit.

${ }_{10}$ A. Niekrewicz, Stowo a obraz..., s. 13.

${ }^{11}$ Ibidem, s. 16.

${ }^{12}$ Karykaturom A. Orłowskiego, autor trzytomowej Historii literatury rosyjskiej, poświęcił osobny tom. Zob. В. Верещин, Русская карикатура, t. 3, Sankt-Petersburg 1913, s. 47.
} 
w przednich trzyma łapcie, co zdaje się wskazywać, że zabrał je chłopu i teraz sprzeda wronom ${ }^{13}$.

Oczywiście, przedmiotem działania karykaturzystów były także bieżące kwestie polityczne w poszczególnych państwach, walki partii politycznych i stronnictw. Należy także odróżnić karykaturę społeczną, obyczajową od karykatury politycznej, która w XIX w. stała się narzędziem polityki państwa i instrumentem polityki międzynarodowej. W literaturze zwraca się uwagę, że karykatura polityczna nie może być traktowana jedynie jako przedmiot komunikacji między nadawcą a odbiorcą. Nie powinno się jej utożsamiać z rysunkiem humorystycznym. Karykatura polityczne jest bowiem ilustrowaną satyrą polityczną. Służyć ma pewnej idei, wyrażać określone poglądy polityczne ${ }^{14}$. Będąc instrumentem polityki międzynarodowej państwa, podporządkowuje się interesom politycznym tego państwa, zwalczając przeciwników określonego reżimu bądź porządku. Tak więc karykatura polityczna w aspekcie stosunków międzynarodowych jawi się jako pozornie pokojowa broń, pozostająca w rękach władzy wykonawczej. Oczywiście, podmioty, chcące skorzystać z tej broni, winny umieć wykorzystać działalność artystów, będących wykonawcami zamierzeń rządzących. Tak więc, karykaturzyści - oczywiście nie wszyscy - w różnych okresach historycznych, z natury rzeczy realizują cele polityczne władzy, przetwarzając jej ocenę sytuacji

${ }^{13}$ Zob. Э. Ацаркина, Александр Осипович Орловский, Москва 1971, с. 62. Niedźwiedź na rysunku jest jednym z pierwszych wyobrażeń Rosji. Jego archetyp zaczęto wykorzystywać jeszcze w XVII w. (zob. Ф. Д. Лиштенан, Вольтер: Фридрих II или Петр I, в: А. Михайлов, А. Строев (ред.), «Вольтер и Россия», Москва 1999, с. 83-80. Porównanie Rosji do niedźwiedzia zdaje się wynikać z wypowiedzi Fryderyka II, który informował Woltera, że jego ojciec, Fryderyk Wilhelm, uważał Moskwicinów za niedźwiedzie, których nie należy spuszczać z łańcucha, bo inaczej nie dałoby się ich z powrotem zakuć. Niedźwiedź jako archetyp Rosjanina pojawia się jednak znacznie wcześniej. W kwestii tej zob. m.in. M. Żakowska, Niedźwiedź i zegarmistrz. Uźródeł Metafory „rosyjskiego niedźwiedzia” w Szwajcarii w drugiej połowie XIX w., „Klio”, 2012, Nr 20(1). Wskazuje się, że kulturze rosyjskiej obraz niedźwiedzia przedstawiony jest z jednej strony pozytywnie w formie prostodusznego głupawego misia, z drugiej prezentuje się jak zwierz dziki i okrutny. Ż. Sładkiewicz, Kubuś Puchatek czy dzika bestia - oblicza „rosyjskiego niedźwiedzia” we wspótczesnej karykaturze politycznej, „Studia Rossica Gedanensia”, 2004, nr 1, s. 431-453; А. А. Россомахин, В.М. Успенский, Д. Г. Хрусталёв, Его величество медведь. 400-летию дома Романовых посвящุается, «Лабиринт», 2013, № 4, s. 27; М.Ю. Тимофеев, Русский медведь/Russian Bear. Потребительские свойства, [w:] «Русский медведь». История, семиотика, политика. Red. O.B. Рябов, А. де Лазари, Москва 2012, s. 313-323; М. Литовская, С. Кропотов, Русский медведь из медвежьего края: интерференция традиционой зоосимволики и персональных свойств личности в репрезентации первого президента РФ, [w:] „«Русский медведь». История, семиотика, политика”, Red. O.В. Рябов, А. де Лазари, Москва 2012, s. 283-296.

${ }_{14}$ T. Sikorski, Karykatura polityczna jako źródto do badań nad historia Drugiej Rzeczypospolitej. Postulaty badawcze, „Historia i Polityka. Półrocznik poświęcony myśli politycznej i stosunkom międzynarodowym", wiosna 2009, nr 1(8), s. 68-69. Zob. także T. Szarota, Niemcy i Polacy. Wzajemnie postrzeganie $i$ stereotypy, Warszawa 1986, s. 101-126. 
oraz zamierzenia na mniej lub bardziej dowcipne prześmiewcze rysunki. Oczywiście nie ma najmniejszej wątpliwości, że karykatura pełni funkcje rozrywkową, ale karykatura polityczna ma jeszcze inne zadania, gdyż kreuje oraz porządkuje rzeczywistość społeczno-polityczną i skłania do przemiany struktury społecznej, jednak unika dogłębnej pełnej analizy obrazowanych zdarzeń. Nie da się także zaprzeczyć funkcji psychologicznej karykatury, rozładowującej lub wzmagającej agresję odbiorcy. Nie sposób przy tym nie zauważyć, że liczne komunikaty zawartych w karykaturach stają się po latach niezrozumiałe dla czytelników. Nieczytelne bądź niezrozumiałe okazują się kody kulturowe, symbole, sytuacje, konteksty znaczeniowe. Aluzje, przenośnie i metafory okazują się być nieczytelne, wymagające niekiedy obszerniejszej analizy, jak również obszernej wiedzy politycznej, historycznej, kulturowej, a nawet językowej w sytuacji, gdy mamy do czynienia z grą słów lub frazeologizmami w podpisach pod karykaturami ${ }^{15}$.

Karykatura, podobnie jak przekaz w prasie drukowanej, ,żyje” stosunkowo krótko. Obie te formy przeznaczone są w zasadzie do „natychmiastowej konsumpcji”. Podejmujący po latach, czasem po dziesięcioleciach, badacz, starający się dociec roli i zadań karykatury w chwili jej powstania, musi rozkodować symbole, znaki, pojęcia, którymi posługiwał się karykaturzysta, zrozumieć jego język, odczytać kontekst historyczny i kulturowy, rozszyfrować zobrazowane w karykaturze postacie, których wygląd dla współczesnych był całkowicie czytelny, nawet jeśli były to postacie drugoplanowe. Kto ze współcześnie żyjących, nawet wykształconych młodych ludzi pamięta jak wyglądał Józef Beck, Bolesław Wieniawa-Długoszowski czy Marian Krzaklewski bądź Piotr Jaroszewicz? Ważne jest także rozważenie, do kogo była kierowana karykatura i co twórca, a także jego ewentualni mocodawcy, chcieli osiągnąć. Jaki cel im przyświecał?

Karykatura jest kapitalnym źródłem dla historyków prawa, ale przecież nie tylko, gdyż jej przekazy nie mogą być obojętne dla parających się historią polityczną, kulturoznawców, historyków sztuki, a także socjologów, prasoznawców i psychologów. Niezbędna jest wnikliwa krytyka tego źródła wymagająca od badacza gruntownej wiedzy ${ }^{16}$. Oczywiście można traktować każdą karykaturę w kategoriach rozrywki, można ją także analizować jako dzieło sztuki, badać treści formalne, ale jest ona przede wszystkim komunikatem wysyłanym przez nadawcę do odbiorcy w ściśle określonym celu. Problem w tym - i to jest najtrudniejsze do

15 А. С. Айнутдинов, Типология и функиии карикатуры в прессе, „Вестник ЧелГУ”, 2008, $\operatorname{nr} 21$, s. 20-28; Е. В. Талыбина, Н. А. Минакова, Карикатура как взаимодействие вербальных и невербальных знаковых систем, „Вестник РУДН. Серия: Русский и иностранные языки и методика их преподавания”, 2013, nr 1, s. 24-30.

${ }_{16}$ M. Porębski, Uczeni do uczonych, [w:] idem, „Pożegnanie z krytyką”, Kraków-Wrocław 1983, s. 192. 
ustalenia - czy cel ten wynika z preferencji twórcy, czy też został wskazany przez czynniki zewnętrzne, osoby sprawujące władzę.

Karykatura, podobnie jak satyra, nie jest i z założenia nie może być obojętna na zjawiska i procesy społeczne frapujące potencjalnych odbiorców. Stara się ona kształtować ich światopogląd, narzuca im kliszę odbioru wydarzeń politycznych. Oczywiście dzięki satyrze można poznać poglądy wydawców, dziennikarzy, a w dużej mierze także stanowiska zajmowane przez rządzących, a przynajmniej przez ich część. W literaturze podkreśla się, że karykatura będąc jednocześnie orężem walki politycznej i dziełem sztuki wymaga od badacza pewnej wiedzy historycznej i umiejętności łączenia kilku występujących w niej wątków tematycznych ${ }^{17}$. Zauważa się możliwość wieloznacznych naukowych interpretacji tego szczególnego źródła ikonograficznego, jakim jest karykatura, podkreślając że w toku badań wypada korzystać z metod badawczych stosowanych w historii sztuki $^{18}$, prasoznawstwie ${ }^{19}$ oraz całej palety metod historycznych ${ }^{20}$, zbliżonych do nich metod politologicznych ${ }^{21}$. Nie ulega wątpliwości potrzeba badań karykatur pod kątem ich związków ze świadomością społeczną i opinią publiczną, którą kształtują bądź usiłują kształtować, ale od której są także zależne ${ }^{22}$. Oczywiście analiza karykatur, jako jednego z wielu źródeł historycznych może wzbudzać liczne wątpliwości i prowokować do rozmaitych pytań. Pominąć tu wypada trudne oceny kategorii komizmu analizowane przez J. Bystronia ${ }^{23}$ i B. Dziemidoka ${ }^{24}$.

17 O. Bergmann, „Prawdziwa cnota krytyk się nie boi...” Karykatura w czasopismach satyrycznych Drugiej Rzeczypospolitej, Warszawa 2012, s. 34.

18 Do przydatnych metod badawczych z zakresu historii sztuki należą: opis preikonograficzny, czyli ocena tego, co dane dzieło bezpośrednio przedstawia; analiza ikonograficzna, badająca dzieło ikonograficzne pod kątem powiązań z innymi źródłami historycznymi, symbolami, motywami, alegoriami; wreszcie interpretacja ikonograficzna, sprowadzająca się do analizy dzieła sztuki pod kątem psychologii ludzkiego umysłu i starająca się powiązać je z przejawami kulturowymi i ich symboliką. Zob. E. Panofsky, Studia z historii sztuki, Warszawa 1971, passim.

${ }_{19}$ Wśród metod prasoznawczych przydatnych do badania karykatur wymienia się: metodę analizy i krytyki źródeł (zarówno zewnętrzną, jak zwłaszcza wewnętrzną); metody statystyczne oraz metodę ilościowej i jakościowej analizy zawartości prasy, a także metodę analizy treści. M. Kafel, Prasoznawstwo. Wstęp do problematyki, Warszawa 1969, s. 106 i n.

${ }^{20}$ Kwestie te szczegółowo omawia B. Miśkiewicz, Wstęp do badań historycznych, Poznań 1988, s. 215-257; idem, Wprowadzenie do badań historycznych, Poznań 1993, s. 163-180. Por. także W. Werner, Wprowadzenie do historii, Warszawa 2012, s. 95-108; A. Świerzawski, Warsztat naukowy historyka. Wstęp do badań historycznych, Częstochowa 2001, s. 156-170.

${ }^{21}$ Zob. A.J. Chodubski, Wstęp do badań politologicznych, Gdańsk 2004, s. 116-131; W. Ph. Shively, Sztuka prowadzenia badań politologicznych, Poznań 2001, s. 50-61.

22 S. Kuśmierski, Świadomość społeczna, opinia publiczna, propaganda, Warszawa 1987, s. 90 i n.

23 J. S. Bystroń, Komizm, wyd. 2, Wrocław 1960, passim. Wskazuje on na komizm zmiany, zestawienia, związku, komizm charakterów oraz komizm słowny.

${ }^{24}$ B. Dziemidok, O komizmie, Warszawa 1967, passim. Autor ten proponuje szereg typologii komizmu, odwołując się do bogatej literatury światowej. Zob. także J. Trzynadlowski, Komizm..., 
Nie ulega także wątpliwości potrzeba analizowania karykatur jako jednego z narzędzi kształtowania stereotypów i mitów politycznych ${ }^{25}$. Z tą ostatnią kwestią łączy się problem roli procesów stereotypizacji w stosunkach międzynarodowych

„Studia literackie”, Wrocław 1955, s. 77; B. Zawadzki, Przeglad ważniejszych teorii komizmu, „Przegląd Filozoficzny” 1929, s. 17; M. Wallis, O przedmiotach komicznych, „Wiedza i Życie” 1938, nr 5-6, s. 385 i n.; J. Sully, An Essay of Laughter, London 1902.

${ }^{25}$ Zob. w tym przedmiocie T. Biernat, Mit polityczny, Warszawa 1989, s. 115-163; T. Saisńska-Klass, Stereotypy i ich odzwierciedlenie w opinii publicznej, [w:] A. Kasińska-Metryka, M. Gołoś (red.), „Mity i stereotypy w polityce. Przeszłość i teraźniejszość”, Torun 2010, s. 7-20; J. Jaskiernia, Rola mitów i stereotypów w procesie integracji europejskiej, [w:] A. Kasińska-Metryka, M. Gołoś (red.), „Mity i stereotypy w polityce...”, s. 92-109; R. Grzegorczykowa, O rozumieniu prototypu $i$ stereotypu we wspótczesnych teoriach semantycznych, [w:] „Język a kultura”, t. 12, J. Anusiewicz, J. Bartmiński (red.), „Stereotyp jako przedmiot lingwistyki. Teoria, metodologia, analizy empiryczne", Wrocław 1998, s.109-115; J. Schmidt, Granica i stereotyp, Międzychód 1997, s. 77114; C.N. Macrae, Ch. Stangor, M. Hewstone, Stereotypy i uprzedzenia. Najnowsze ujęcie, Gdańsk 1999, s. 13-130; J. Maternicki, Historiografia i mity, [w:] A. Czyżewski, R. Stobiecki, T. Toborek, N. Zaszkilniak (red.), „Mity i stereotypy w dziejach Polski i Ukrainy w XIX i XX wieku”, Warszawa-Łódź 2012, s. 11-25; K. Polasik-Wrzosek, Etnografia, etnologia jako świadectwo stereotypu etnicznego, A. Czyżewski, R. Stobiecki, T. Toborek, N. Zaszkilniak (red.), „Mity...”, s. 55-64; J. Błuszkowski, Stereotypy a tożsamość narodowa, Warszawa 2005, s. 15-33 i 67-89; A.F. Grabski, Historiografia - mitotwórstwo, mitoburstwo, [w:] A. Barszczewska-Krupa (red.), „Historia, mity, interpretacje", Łódź 1996, s. 29-62; I. Kurcz, Zmiana stereotypów: jej mechanizmy i granice, [w:] M. Kofta, A. Jasińska-Kania, „Stereotypy i uprzedzenia”, Warszawa 2001, s. 3-21, tejże, Zmienność i nieuchronność stereotypów. Studium na temat roli stereotypów w reprezentacji umystowej świata społecznego, Warszawa 1994, s. 11-79; A. Kłosowska, Stereotypy a rzeczywistość narodowej identyfikacji i przyswojenia kultury, [w:] A. Barszczewska-Krupa (red.), „Historia...”, s. 83-104; A. Kępiński, Lach i Moskal. Z dziejów stereotypu, Warszawa-Kraków 1990, s. 7-15 i 164-219; T. Szarota, Niemcy i Polacy. Wzajemne postrzeganie i stereotypy, Warszawa 1996, zob. rozdział „Polak w karykaturze niemieckiej 1914-1944. Przyczynek do badań stereotypów narodowych”, s. 101-137; H.H. Hanh, Stereotypy - tożsamość - konteksty. Studia nad polska i europejska historia, Poznań 2011, s. 31-130; W. Stankiewicz, Powstawanie i funkcjonowanie stereotypów oraz uprzedzeń w relacjach międzyludzkich, [w:] E. Ponczek, A. Sepkowski, M. Rekść, „Mity polityczne i stereotypy w pamięci zbiorowej społeczeństwa", Łódź 2015, s. 249-270; S. Olszyk, Stereotyp wroga w walce wyborczej w Polsce 1991-2011, Toruń 2013, s. 27-74; J. Sobczak, Stereotyp wroga, [w:] K. Glass, Z. Puślecki, B. Serloth (red.), „Obcy. Sąsiedzi. Niechciani partnerzy?”, Toruń 1995, s. 93-100; tenże, Literackie korzeń stereotypu Litwina, [w:] J. Sobczak (red.) „Media i Polityka” t. 1, Poznań-Września 2001, s. 237-274 (w pracy tej obszerne zestawienie literatury dotyczącej miejsca stereotypu w naukach społecznych oraz kształtowania się stereotypów narodowych, a także wpływowi na opinie i zachowania poszczególnych jednostek, jak i grup społecznych, wreszcie zgodności stereotypu z obiektywnie istniejącym stanem rzeczy); idem, Stereotyp Litwina w świadomości historycznej spoteczeństwa Rzeczypospolitej szlacheckiej, [w:] M. Kosman (red.), „Kultura polityczna w Polsce”, t. 2, 1999, s. 93-102; idem, Stereotyp Mongoła i Tatara w świadomości społeczeństwa polskiego, [w:] K. Borowczyk, P. Pawełczyk (red.), „W kręgu mitów i stereotypów”, Toruń 1993, s. 76-93; W. Wrzesiński (red.), Wokót stereotypów Niemców i Polaków, Wrocław 1993, passim; D. Jarosz, Uwagi o polskiej literaturze naukowej na temat stereotypów, „Dzieje Najnowsze” 1991, R. XXIII, nr 2, s. 93-104; T. Wallas, Narody i stereotypy, Kraków 1995, passim. 
dotyczących z jednej strony ich funkcji w formowaniu tożsamości narodowej ${ }^{26}$, z drugiej z funkcjami obronnymi i mobilizującymi społeczeństwo ${ }^{27}$, a także kwestia autostereotypu Polaków ${ }^{28}$. Zauważa się przy tym, że stereotypy narodowe pełnią ważne funkcje polityczne związane z kształtowaniem stosunków międzynarodowych służąc artykulacji interesów grup narodowych i etnicznych. Są przy tym instrumentalnie wykorzystywane $\mathrm{w}$ celach propagandowych i manipulacyjnych ${ }^{29}$. W kształtowaniu, a jeszcze bardziej w ich utrwalaniu olbrzymią rolę odgrywa karykatura.

Pełna analiza karykatur politycznych przekracza z natury rzeczy ramy niniejszego artykułu, a przyjęta konwencja wydawnicza nie pozwala na przedstawianie licznych karykatur także z tej przyczyny, że w odniesieniu do ostatnich lat są one objęte ochroną z racji tak osobistych, jak i majątkowych praw autorskich. Prace dotyczące karykatur politycznych są stosunkowo nieliczne ${ }^{30}$, a podejmowane

${ }^{26}$ Zauważa się przy tym, że problematyka tożsamości narodowej wiąże się z wewnętrznym oglądem własnego narodu. Zob. w tej kwestii J. Berting, Ch. Villain-Gandossi, Rola i znaczenie stereotypów narodowych $w$ stosunkach międzynarodowych: podejście interdyscyplinarne, [w:] T. Walas (red.), „Narody i stereotypy”, Kraków 1995, s. 13-27. Wskazuje się też, że problematyka tożsamości narodowej obejmuje istotną część zainteresowań transformacjami narodów i zróżnicowaniami etnicznymi występującymi w granicach państw. Zob. Z. Bokszański, Tożsamości zbiorowe, Warszawa 2005, s. 101. W kwestii tej por. także, A. Kłosowska, Tożsamość i identyfikacja narodowa w perspektywie historycznej i psychospołecznej, „Kultura i Społeczeństwo” 1992, nr 1, s. 132; eadem, Kultury narodowe u korzeni, Warszawa 1996, s. 97-99; Z. Bokszański, Stereotypy a kultura, Wrocław 1997, s. 90 i n. Nadbudowę psychiczną narodu tworzą, jak wskazuje się w literaturze, obok czynników politycznych, obejmujących prawo i rząd, także czynniki religijne i kulturowe, do których należy język, literatura, myśl ludzka, a także przekazy ikonograficzne, a więc także karykatury. E. Baker, Charakter narodowy i ksztattujace go czynniki, Warszawa 1933, passim; G. Gore, The Concept of national charakter, [w:] C. Kluckhohn, H.A. Murray, A.A. Knopf (red.), „Personality in nautre, socjety and culture”. New York 1956, s. 249; J. Błuszkowski, Stereotypy a tożsamość narodowa, Warszawa 2005, s. 24-25.

${ }^{27}$ Zwolennicy teorii konfliktu interesów wskazują, że stereotypy są efektem konkurencji między grupami w osiąganiu pożądanych dóbr, których zasoby są ograniczone. Zob. Z. Chlewiński, Stereotypy: struktura, funkcje, geneza. Analiza interdyscyplinarna, [w:] Z. Chlewiński, I. Kurcz (red.), „Stereotypy i uprzedzenia”, Warszawa 1992, s. 21. Wskazuje się, że stereotypy pełnia cztery funkcje pragmatyczne: integrującą, obronną, ideologiczną i polityczną. Pierwsza z nich wiąże się z podziałem na swoich i obcych. Zob. A. Schaff. Stereotypy a dziatanie ludzkie, Warszawa 1981, s. $39-43$ i $127-136$.

${ }^{28}$ L. Kołakowski, O stereotypach narodowych, [w:] „Mini wykłady o maxi sprawach”, Kraków 2001, s. 102; R. Scruton, Oikofobia i ksenofobia, [w:] T. Walas, „Narody i stereotypy”..., 291-297.

29 J. Błuszkowski, Stereotypy..., s. 27.

${ }^{30}$ Zwrócić jednak wypada uwagę na rozważania J. Ślęzak, Wybrane aspekty polityki zagranicznej Stanów Zjednoczonych w świetle karykatur zamieszczanych na łamach „Nowin Rzeszowski” w latach 1949-1953, [w:] Ł. Kamiński, T. Kozłwoski (red.), „Letnia Szkoła Historii Najnowszej 2010”, Warszawa 2010, s. 46-58; J. Ślęzak-Gotkowska, ZSRR i obóz państw socjalistycznych w karykaturze okresu socrealizmu - na przykladzie wybranych rysunków opublikowanych $w$,, Trybunie Ludu” w latach 1950-1955, „Prace Naukowe Akademii im. Jana Długosza w Częstochowie. Rex 
w nich analizy dotyczą głównie warstwy ilustracyjnej. W tym stanie rzeczy należało ograniczyć się to przedstawienia politycznych karykatur jedynie z obszaru Polski i Rosji, rezygnując - wobec gorsetu praw autorskich - z reprodukcji omawianych przekazów ikonograficznych.

Wszelkie zmiany społeczne, a przede wszystkim wojna, zawsze jest katalizatorem karykatury politycznej. Im mocniejsze jest starcie, tym w bardziej jaskrawy i negatywny sposób ukazywany jest wróg. Pierwsza wojna światowa zmieniła podejście do roli karykatury politycznej, ale także rozwinęła ją. Znacząco wzrosły nakłady prasy satyrycznej. Karykatury były publikowane zarówno w codziennej prasie, ale także ukazywały się na pocztówkach i plakatach. Wiele wydawnictw publikowało bezpłatne ilustrowane ulotki skierowane do żołnierzy, które następnie z samolotów i balonów powietrznych zrzucano do okopów wroga ${ }^{31}$. Zarówno państwa Ententy, jak i Trójprzymierza zaostrzyły cenzurę, obejmującą całą prasę, czyli także karykaturę polityczną, która została „zmobilizowana na służbę interesom obrony państwa”. Państwa za pośrednictwem specjalnych agencji finansowały karykaturzystów i podsuwały im „właściwe” tematy 32.

Początek wojny był związany z patriotycznym uniesieniem we wszystkich państwach uczestniczących w konfliktach wojskowych. Karykaturzyści uważali, że rysunkami udzielają wsparcia moralnego walczącym na froncie żołnierzom. W czasie konfliktu karykatura nie tylko prowokuje agresję, ale także neutralizuje strach $^{33}$. Głównym celem karykatur okresu I wojny światowej stał się cesarz Wilhelm II, w którego osobie, jak w soczewce, skupiły się wszystkie negatywne stereotypy. Cesarza przedstawiano jako diabła lub antychrysta, siedzącego na dziku,

Politicae" 2014, t. VI, s. 109-124; J. Ślęzak, Karykatura socrealistyczna o wojnie w Korei - na przykładzie wybranych rysunków satyrycznych opublikowanych na łamach ,,Trybuna Ludu” w latach 1950-1953, „Prace Naukowe Akademii im. Jana Długosza w Częstochowie. Rex Politicae” 2011, t. IV, s. 253-269; D. Demski, Obrazy ,innych” w karykaturach - temat dla etnografa?, „Etnografia Polska" 2008, t. II, z. 1-2, s. 93-115.

31 J.-C. Gardes, La caricature en guerre: Allemagne, 1914-1918, "Le Temps des Medias”, 2005, nr 4, s. 152.

${ }^{32}$ Zob. Szerzej J.-C. Gardes, La caricature..., s. 151-152; В. Славенсон, Милитарная карикатура, „Русская мысль”, 1916, nr 6, s. 29; П. Томпсон, Рабочее движение и карикатура, Москва-Ленинград 1926, s. 77.

${ }^{33}$ W. A. Coup, Observations on a Theory of Political Caricature, "Comparative Studies in Society and History”, 1969, Vol. 11, nr 1, s. 91. Karykaturzyści z niemieckiego czasopisma „Kladderadatsch" stwierdzali, że realizują misję narodową, gdyż humor pomaga walczyć. Por. Zob. szerzej J.-C. Gardes, La caricature..., s. 152. Podobne stanowisko prezentowali także rosyjscy karykaturzyści. Wiera Sławienson w 1916 r. na łamach „Русской мысли” twierdząc, że gdyby przyjąć, że człowiek jest istotą śmiejącą się, że śmiech, zgodnie z poglądami Woltera i uwzględnieniem Kanta, tak samo niezbędne, na przekór wielu cierpieniom w życiu, jak sen i nadzieja, wzmocnił się i brzmi głośno i pewnie. Śmiech słychać nie tylko na tyłach frontu, lecz także w okopach. Por. В. Славенсон, Милитарная карикатура ..., s. 27. 
szalonego psa w hełmie ze szpicem, jako monstrum, tyrana, kata etc. Na jednej z brytyjskich karykatur Grzegorz V zrywa Wilhelmowi II Order Podwiązki, w następstwie czego cesarzowi spadają spodnie i ukazuje się jego diabelski ogon i pokryte futrem zwierzęce kończyny ${ }^{34}$. Niemiec w karykaturach był przedstawiany z wąsami jak u cesarza, np. jako masarz z głową świni, kiełbasami i parówkami ${ }^{35}$. Wyśmiewane było także uzbrojenie, jakim dysponowali Niemcy - na karykaturze „Kiedy świnie zaczęły latać” ukazano sterowce w kształcie świnek z anielskimi skrzydłami, zrzucające na Londyn bomby w kształcie kiełbasek ${ }^{36}$.

Właśnie cesarz Wilhelma II był postrzegany jako główny winowajca rozpętania I wojny światowej. Wielokrotnie na rosyjskich karykaturach przedstawiano cesarza jako wariata cierpiącego na megalomanię, który podobnie Napoleonowi, marzy o zawładnięciu całym światem. Odniesienie do Napoleona w rosyjskiej karykaturze należy wiązać z tym, że I wojny światowej, wówczas była określana mianem „Drugiej Wojny Ojczyźnianej”, zestawianej ze zwycięską dla Rosji „Wojną Ojczyźnianą” 1812 r., gdy wojska napoleońskie wkroczyły na teren imperium carów. $Z$ tego powodu utożsamianie Wilhelma II z Napoleonem było nadzwyczaj popularne w rosyjskiej karykaturze okresu I wojny światowej.

W państwach Ententy, tworzone były powtarzalne schematy przedstawiania przeciwnika w karykaturach. Powstała wówczas cliché cywilizowanego barbarzyńcy prezentowana była w karykaturach rosyjskich, ale też brytyjskich. Niemiec przedstawiany był jako dzikus siedzący na książkach Kanta, Hegla i innych niemieckich filozofów obgryzający dziecięcą nóżkę̨7. Powstanie tego obrazu jest łączone m.in. z wypowiedzią Wilhelma II, który w 1900 r. wysyłając wojska w celu stłumienia powstania bokserów, nawoływał aby żołnierze zachowywali się jak Hunowie pod przywództwem Attyli i nie mieli litości dla Chińczyków ${ }^{38}$.

${ }^{34}$ E.J. Sullivan, The Kaiser 's Garland, London 1915, s. 47, https://ia902703.us.archive.org/13/ items/kaisersgarland00sull/kaisersgarland00sull_bw.pdf [dostęp: 29.10.2017].

${ }_{35}$ Х.Ф. Ян, Русские рабочие, патриотизм и Первая мировая война, [w:] С.И. Потолов (red.), „Рабочие и интеллигенция России в эпоху реформ и революций. 1861 -февраль 1917 г.: материалы Междунар. коллоквиума, 12-15 июня 1995 г.”, Санкт-Петербург 1997, s. 384.

${ }^{36}$ E.J. Sullivan, The Kaiser's Garland, London 1915, s. 67, https://ia902703.us.archive.org/13/ items/kaisersgarland00sull/kaisersgarland00sull_bw.pdf [dostęp: 29.10.2017].

37 И.П. Флеровский, Война и карикатура, „Современник”, 1914, nr 10, s. 280.

${ }^{38}$ W.A. Coupe, Kaiser Wilhelm and the Cartoonists, "History Today", 1980, nr 11, s. 16-23. Jeszcze w okresie przedwojennym można zaobserwować podobne sposoby przedstawiania niektórych zagadnień, polityków czy narodów w karykaturach państw późniejszej Ententy, np. Niemcy byli kojarzeni z uwielbieniem dla kiełbasy, wojowniczością, racjonalnością i punktualnością. Opublikowana w czasopiśmie „Punch” karykatura Brawo Belgia!, ukazała po wkroczeniu Niemiec na teren neutralnej Belgii, co stało się podstawą do przystąpienia do wojny Wielkiej Brytanii. Agresję Niemiec wobec Belgii ukazano jako pojedynek Dawida i Goliata, gdzie Niemcy ukazane zostały jako obwieszony kiełbaskami zły grubas. Niemiec robi zamach maczugą, a belgijski chłopiec bohatersko broni bramy z napisem „Przejazd zakazany” Zob. szerzej H.P. Adam, International Car- 
Rosja była przedstawiana w postaci niedźwiedzia na długo przed początkiem I wojny światowej ${ }^{39}$. Na francuskich i brytyjskich karykaturach Rosja ukazywana była jako „oddany wspólnej sprawie sojusznik”, przy tym silny, natomiast niemiecka karykatura, widząc w Rosji także niedźwiedzia, przedstawiała go jako „wroga, który umie jedynie się odgrażać”.

Stałe śledzenie wydarzeń na frontach I wojny światowej skutkowało szczegółową znajomością mapy politycznej, co pozwalało na odnoszenie się w karykaturach do kształtów poszczególnych państw. Rosja zwyczajowo ukazywana była jako niedźwiedź, a duża powierzchnia państwa pozwalała na dopasowanie niedźwiedzia do jego kształtu. Ponadto Rosję ukazywano jako zgarbionego starca, czy walca jadącego na Europę zrównując wszystko na swojej drodze ${ }^{40}$.

Dwudziestolecie międzywojenne było z jednej strony okresem rozwoju gospodarczego, poczucia stabilności u całego pokolenia, które wychowało się po wojnie, znalazło odzwierciedlenie w koncentrowaniu się karykaturzystów na elementach życia codziennego. $\mathrm{Z}$ drugiej zaś strony był to także okres stanowienia wielu systemów totalitarnych w Europie. Systemy totalitarne charakteryzują się chęcią przejęcia kontroli nad obywatelami, w tym nad ich myślami i poglądami, a także zmobilizowaniem całego społeczeństwa lub większej jego części dla realizacji wspólnego, wytyczonego przez państwo celu. Dla państw totalitarnych, których społeczeństwa w dużej mierze stanowili analfabeci, karykatura była nie-

toons of the War, New York 1916, https://ia600308.us.archive.org/24/items/internationalcar00adam/internationalcar00adam_bw.pdf [dostęp: 29.10.2018]; L. R. Moyle, "Drawing Conclusions»: An Imagological Survey of Britain and the British and Germany and the Germans in German and British Cartoons and Caricatures, 1945-2000, praca doktorska została obroniona na Uniwersytecie w Osnabrück, 2004, https://d-nb.info/974194158/34 [dostęp: 29.10.2017].

39 Rosja w postaci niedźwiedzia pojawia się już w XVIII w. na angielskich obrazach i grafikach. W okresie wojen napoleońskich na karykaturach politycznych rosyjski niedźwiedź ukazywany był na uwięzi oraz w postaci żołnierza, a także jako heraldyczne zwierzę oraz gwiazdozbiór [gwiazdozbiory Wielki i Mały Wóz są określane mianem Wielkiej i Małej Niedźwiedzicy - przyp. K.K.]. Od połowy XIX w. do początku XX w. był przedstawiany dwojako i stanowił odzwierciedlenie postrzegania rosyjskiej polityki zagranicznej. $Z$ jednej strony niedźwiedź utożsamiany z Rosją był agresywnym i dzikim drapieżnikiem, z drugiej zaś jako śmieszne i nieporadne zwierzę. W niemieckiej karykaturze obecny był motyw pięknej i bestii będące przenośnią Europy i Rosji. W przekazach angielskich można znaleźć karykaturę przedstawiającą brytyjskiego lwa, leżącego kota perskiego oraz siedzącego rosyjskiego niedźwiedzia przejawiającego upór drapieżnika. Zob. w tym temacie Д. Хрусталев, Происхождение русского медведя, „НЛО” 2011, nr 107, s. 137; В. Успенский, Типология изображений русских медведей в европейской карикатуре XVIII - первой трети XIX веков, [w:] О.В. Рябова и А. де Лазари (red.) „«Русский медведь»: история, семиотика, политика"Moskwa 2012, s. 87, 88, 94, 101, 102; М. Жаковска, Медведь на охоте, охота на медведя: Россия в немецкой карикатуре $X I X$ и XX вв., „Политическая лингвистика”, 2011, nr 1, s. 15-16; The Harmless Necessary Cat, „Punch”, 1907, vol. 133, s. 245.

${ }_{40}$ М. Жарковска, Медведь на охоте, охота на медведя: Россия в немецкой карикатуре $X I X$ $u X X$ вв., „Политическая Лингвистика”, 2011, nr 1(35), s. 15-19. 
zastąpionym instrumentem wpływu, ukształtowania ,,jedynej słusznej ideologii” i wytyczenia wspólnego celu ${ }^{41}$. W karykaturze szeroko wykorzystywane były, ugruntowane już w świadomości ludzkiej, stereotypy narodów: Polaków, Litwinów, Niemców czy Rosjan zastępowane były obrazami Polski, Litwy, Niemiec i Rosji, odwołując się do wcześniej znanych stereotypów ${ }^{42}$. Przenosiło to dyskusję na poziom międzynarodowy, wymuszając na społeczeństwie powszechną wiedzę o sytuacji w Europie oraz w efekcie kształtując pozornie własną, ale wytyczoną przez państwo, ocenę.

$\mathrm{Na}$ etapie stanowienia władzy radzieckiej, dominującą prasą była bolszewicka. Dla komunistów ważne były działania wojskowe, ale równie wysoko cenili działania propagandowe. Do połowy lat dwudziestych szeroko reprezentowane były nurty zarówno popierające władzę, ukazujące np. Lenina stojącego na globie ziemskim, i przy użyciu dużej miotły, przypominającej odwróconą flagę komunistyczną, czyszczącego świat ze zła, usuwającego opasłych burżujów, carów i duchownych ${ }^{43}$. Na uwagę zasługuje fakt, że publikowane najpierw w prasie karykatury następnie były rozpowszechniane w postaci plakatów propagandowych. Głównymi bohaterami byli z jednej strony bohaterscy działacze bolszewiccy, z drugiej wszyscy przeciwnicy radzieckiej władzy w kraju i zagranicą. Po wyeliminowaniu „wrogów” władzy komunistycznej tematyka karykatury nieco się zmieniła, skupiając się na sytuacji międzynarodowej, wskazując kto jest sojusznikiem, a kto potencjalnym wrogiem państwa radzieckiego.

W karykaturach ukazujących się w prasie innych państw europejskich można było zaobserwować pewną dość trwałą tendencję, zmierzającą początkowo do wyjaśnienia i wskazania przesłanek, przyczyn oraz winnych rozpętania I wojny światowej, sposobu jej zakończenia i konsekwencji dla poszczególnych, często nowopowstałych, państw. Następnie w miarę upływu czasu tematyka karykatury

${ }^{41}$ W Związku Radzieckim na etapie kształtowania mocnej władzy i walki z opozycyjnymi ugrupowaniami (1917-1926) odnotowano powstanie wielu tytułów prasy satyrycznej, której zawartość stanowiły głownie karykatury i niewielkie wierszowane satyryczne formy. Wśród nich należy wskazać m.in. «Новый Сатирикон» (1914-1918), «Рабочая Москва» (1923-1926), «Красный перец» (1923-1934), «Красный ворон» (1922-1924), «Бегемот» (1924-1928), «Крокодил». Działalność satyryczna zarówno przez dziennikarzy, grafików, jak też pisarzy była pożądana przez władzę, która postrzegała satyrę jako narzędzie walki z niedociągnięciami i nieprawidłowościami w państwie. Dopiero z umocnieniem się władzy pod rządzami Stalina akceptowana była jedynie satyra wytykająca wady i błędy wszystkich poza władzą. Działania wspierające władzę miały przejawy także tworzenia nowego folkloru - piosenek, bajek, „,zastuszek”. Zob. szerzej С. И. Стыкалин, И. К. Кременская, Советская сатирическая печать 1917-1963, Москва 1963, passim.

42 J. Błuszkowski, Stereotypy a tożsamość narodowa, Warszawa 2005, s. 15-33 i 67-86; A. Kępiński, Lach i Moskal - z dziejów stereotypy, Warszawa-Kraków 1990, s. 7-16 i 164-219; T. Walas (red.), Narody i stereotypy, Kraków 1995, passim.

43 В. Н. Дени, Тов. Ленин очищает землю от нечисти, 1920, http://www.plakaty.ru/plakaty/ voennye/tov_lenin_ochishchaet_zemlyu_ot_nechisti/[dostęp: 01.10.2017]. 
politycznej skupiała się na komentowaniu coraz bardziej skomplikowanej sytuacji międzynarodowej w Europie, wskazując kto jest sojusznikiem, a kto potencjalnym wrogiem, ułatwiając społeczeństwu ocenę sytuacji.

$\mathrm{Na}$ rolę karykatury w radzieckiej polityce wskazuje przyjęcie w sierpniu 1928 r. rozporządzenia KC WKP(b) „o czasopismach satyrycznych”44. W jego tekście zobowiązano organy propagandy do przeprowadzania nie rzadziej niż dwa razy na miesiąc specjalnych narad redaktorów czasopism satyrycznych w celu przekazania im instrukcji i wskazania kierunków pracy. Wskazywano wówczas, że czasopisma wdając się w konkurencję między sobą, coraz bardziej dostosowywały się do odbiorców z kręgów inteligencji, skupiają się na tematach bytowych, zapominając o swoim przeznaczeniu jakim była walka przeciwko przenikaniu do społeczeństwa radzieckiego takich zjawisk jak biurokracja, wulgarne ideologie i negatywne skutki nowej polityki ekonomicznej ${ }^{45}$. W karykaturach realizujących zadania propagandy radzieckiej posługiwano się powtarzalnymi, wyrazistymi obrazami-maskami, np. imperialistę cechowały cylinder, monokl oraz worek pieniędzy, natomiast wojskowi najczęściej mieli mundury Francji, Japonii lub Polski. W dość krótkim czasie odbiorcy bardzo dobrze rozpoznawali w różnych postaciach także cechy czołowych polityków - podbródek Mussoliniego, monokl Chamberlaina, maciejówka i wąsy Piłsudskiego, furażerka z frędzlami i charakterystyczny profil Franko ${ }^{46}$.

Tematyka międzynarodowa w karykaturach nie miała stałego natężenia, a była uzależniona od konkretnych wydarzeń. Niektórym państwom poświęcano wyraźnie więcej uwagi, niż innym - najczęściej karykatury poświęcano Niemcom, Wielkiej Brytanii, Francji, Polsce, Japonii i USA ${ }^{47}$. Tematyka przybliżającej się kolejnej wojny zaczęła pojawiać się w karykaturach radzieckich już w 1928 r. i była obecna przez cały czas do jej rozpoczęcia w 1939 r. Początkowo winą za groźbę wybuchu nowej wojny obarczano Chamberlaina, Poincaré, a następnie „Wujka Sama" ${ }^{\prime 4}$. Nawet podpisanie paktu Brianda-Kellogga i przyłączenie do tego dokumentu ZSRR w sierpniu 1928 r. przedstawione zostało w karykaturach radzieckich jako entuzjastyczne komentarze podpisujących, że najchętniej podpisaliby

${ }^{44}$ Постановление секретариата ЦК ВКП(б) от 3 августа 1928 г. «О сатирических журналах», РЦХИДНИ, Ф. 17, Оn. ИЗ. Д. 646, ЛЛ. 2, 3.

45 Д.Л. Бабиченко (red.), «Счастье литературы». Государство и писатели. 1925 - 1938 гг. Документы, Moskwa 1997, s. 56-58.

46 В.И. Костин, Михаил Михайлович Черемных, Moskwa 1957, s. 14.

47 Na podstawie badań przeprowadzonych w oparciu o karykatury publikowane w czasopiśmie „Крокодил” w okresie 1922-1939, Niemcom poświecono 550 karykatur (ok. 30\%), Wielkiej Brytanii - 300 (ok. 20\%), Francji - 250 (ok. 15\%), Polsce - 170, Japonii - 166, USA - 160. Zob. szerzej А.В. Голубев, «Если мир обрушится на нашу Республику»: Советское общество и внешняя угроза в 1920-1940-е гz., Moskwa 2008, szczególnie rozdział 4.

${ }^{48}$ Б Е. Ефимов, Карикатура на службе обороны СССР, Moskwa-Leningrad, 1931. s. 20. 
ten dokument obiema rękoma, przy jednoczesnym ukazaniu, że każdy z podpisujących w drugiej ręce trzyma za plecami bombę ${ }^{49}$. W 1931 r. została opublikowana karykatura pod nazwą „W szkole Ligi Narodów”, przedstawiająca anioła pokoju, który przychodzi do szkoły Ligi Narodów jako dziecko z gałązką oliwną, a wychodzi z niej jako duży i umięśniony żołnierz w mundurze, uzbrojony, z butlą gazu trującego i planem ataku na ZSRR, za plecami zamiast skrzydeł anielskich widniały skrzydła samolotu ze swastyką. Autorzy karykatury podkreślali, że nauczycielami w tej szkole byli O. Chamberlain i A. Briand ${ }^{50}$. Komentowano także współpracę państw tworzących Trójprzymierze, np. relacje Niemiec i Japonii w karykaturze pt. Matżeństwo z miłości... do cudzych terytoriów przedstawiającej Japończyka, który z zadowoleniem przypatrywał się globusowi zapełnionymi niemieckimi i japońskimi flagami, obejmując Niemcy w rogatym krzyżackim hełmie $z$ blond warkoczem i charakterystycznym wąsikiem ${ }^{51}$. W języku rosyjskim nazwa państwa Niemcy - Германия jest rodzaju żeńskiego, dlatego Niemcy ukazywane są $\mathrm{W}$ postaci kobiety.

Polska karykatura polityczna bezpośrednio po I wojnie światowej za cel brała głównie Prusaków, nie utożsamiając ich z Niemcami, lecz łącząc z Krzyżakami, odnosząc się niewątpliwie do elementu gry słownej zrównującą Prusaków z nienawistnymi insektami. Niemcy były przedstawiane jako nieudolna gospodyni, która nie może pokonać inwazji prusaków. Nie stroniono w karykaturach od odniesienia się do skomplikowanych relacji polsko-litewskich. Na jednej z karykatur ukazano Piłsudskiego, który częstuje psa utożsamiającego Litwę kiełbasą z napisem „Zgoda”, a pies ten szczeka „Wilno! Wilno!”52. Niejednoznacznie rysowały się w karykaturach także relacje polsko-ukraińskie. W karykaturach przedstawiano reprezentantów ze Lwowa do Sejmu RP jako osoby o wątpliwej reputacji, powiązane ze skrajnie prawicowymi ruchami ukraińskimi oraz kręgami żydowskich przedsiębiorców, a nie reprezentujących interesy Polaków ${ }^{53}$.

Jednym z czołowych źródeł karykatury politycznej na terenie Polski był wydawane w latach 1868-1939 czasopismo „Mucha”, z którym współpracowało wielu literatów i rysowników. Na jego łamach ukazywały się karykatury komentujące

49 „Крокодил”, 1928, nr 32, s. 5.

50 „Крокодил”, 1931, nr 23-24, s. 2.

51 Поджигатели войны. Карикатуры Б. Ефимова, Moskwa 1938, s. 67

52 Nie mniej negatywnie ukazywane były stosunki polsko-litewskie w litewskiej karykaturze. Przykładem może służyć karykatura ukazująca gen. B. Wieniawę-Długoszowskiego, który podnosi płytę nadgrobną, wypuszczając z grobu J. Piłsudskiego. Komentarz na karykaturze wskazuje, że adiutant J. Piłsudskiego przybył do Wilna w celu zaopiekowania się grobami swoich bliskich. Na płycie nadgrobnej widnieje napis „Stosunki polsko-litewskie. Pogrzebane 9 października 1920 r.”. B. Wieniawa-Długoszowski stwierdza „Jakże ciężko doprowadzić do porządku ten grób”. Zob. http://p-w-w.org/index.php?topic=14917.0 [dostęp: 03.10.2017 r.].

${ }^{53}$ „Kabaret” z dnia 13 lutego 1928 r. 
zmieniającą się sytuację międzynarodową i stanowiło ono ważniejsze narzędzie popularyzacji oceny wydarzeń politycznych. Pojawiały się m.in. karykatury ukazujące Hitlera częstującego z łyżeczki miodem dziewczynki, utożsamiające Francję i Polsce, stwierdzając „Na razie po łyżce miodu pokoju. A potem zobaczymy, co moje pszczoły wyprodukują". Pszczoły latające w tle uzbrojone są w karabiny, a na głowach mają niemieckie hełmy ${ }^{54}$. Inna karykatura, opublikowana na okładce „Muchy” ukazuje obejmujących się i całujących grubego żołnierza niemieckiego i bardzo wychudzonego żołnierza radzieckiego, a zaklinowany w tych objęciach, rozpychający się łokciami z walecznym wyrazem twarzy, polski oficer w charakterystycznym mundurze ${ }^{55}$.

W pierwszych miesiącach po rozpoczęciu II wojny światowej radziecka propaganda nie wykazuje żadnej zdecydowanej pozycji względem wydarzeń europejskich. W jednej chwili, aż do agresji na teren ZSRR 22 czerwca 1941 r., znikają wszelkie karykatury ukazujące Niemcy, co było niewątpliwie skutkiem podpisania paktu Ribbentrop-Mołotow. Temat Wielkiej Brytanii i Francji w drugiej połowie 1939 r. pojawia się jedynie kilkukrotnie w związku z uciążliwością wojny dla szeregowych obywateli państw europejskich, a nie z politycznym wymiarem sytuacji. Dominować zaczęła wówczas polska tematyka - porażka Polski, „połączenie” Wschodniej i Zachodniej Białorusi w wyniku działań Armii Czerwonej, radosne powitaniem mieszkańców byłych terenów polskich oraz zmiany, jakie zostały wprowadzone na nich pod rządami radzieckimi ${ }^{56}$. Nieco później pojawia się tematyka fińska, związana z trwającą wówczas wojną radziecko-fińską. W $1940 \mathrm{r}$. oraz w pierwszej połowie $1941 \mathrm{r}$. tematy europejskie powracają na strony radzieckich czasopism satyrycznych, a ich głównymi bohaterami są - Wielka Brytania, Francja, polscy emigranci oraz Finowie. Od czasu do czasu pojawiają się również Rumunia i Szwecja. Karykatury głównie poświęcone są tematyce międzynarodowej, przebiegu wojny i problemom, z którymi borykają się uczestniczące w wojnie państwa. Podkreślić należy, że Włochy i Niemcy nie są obecne na tych karykaturach. Dopiero po niemieckiej agresji na obszar ZSRR, Niemcy, Włochy oraz ich sojusznicy byli przedstawiani jako wrogowie, natomiast Wielka Brytania, Francja i Polska, mimo okupacji jej terenów - jako sojusznicy Związku Radzieckiego ${ }^{57}$.

Głównym zadaniem karykatury w okresie II wojny światowej było podniesienie morale zarówno uczestniczących w wojnie wojskowych, jak i znajdujących

54 „Mucha”, r. 65, nr 50 z dnia 8 grudnia 1933 r.

55 „Mucha”, r. 62, nr 38 z dnia 19 września 1930 r.

56 В.А. Токарев, Советский фоторепортаж польской кампании (1939): организация и структура, „Проблемы российской истории”, Магнитогорск, 2006, nr 7, s. 553.

57 Szerzej w tym temacie zob. А.В. Голубев, Образ Европы в советской карикатуре 20-30-х годов, [w:] „Труды Института российской истории”, Moskwa, 2005, nr 5, s. 273-299. 
się poza linią frontu mieszkańców, a także zmobilizowanie do oporu, zachęcanie do pracy na rzecz państwa w okresie wojny. Starano się także o utrzymanie wiary w możliwe zwycięstwo i powrót do życia pokojowego. Zarówno radzieckie, jak i polskie karykatury z okresu II wojny światowej jako wroga ukazywały Niemców jako głupie osoby, zwierzęta ubrane w mundury niemieckie, w późniejszym okresie kościotrupy, jako uosobienie śmierci, którą niosły ze sobą te wojska. Pozytywnym bohaterem był zazwyczaj odpowiednio Polak lub obywatel ZSRR, który dzięki swojemu sprytowi i odwadze zwycięża Niemca ${ }^{58}$.

Rozpoczęcie „zimnej wojny” spowodowały kolejną aktywizację karykatury jako narzędzia komentującego politykę międzynarodową i pozycję ZSRR oraz państw Układu Warszawskiego wobec reszty świata. Podkreślić należy, że polska karykatura polityczna pod wpływem ,wielkiego brata” ZSRR dotyczyła tej samej tematyki oraz korzystała z podobnych środków - wskazanie poprzez wyraziste obrazy-maski państw europejskich jako będących w zmowie przeciwko ZSRR i państwom socjalistycznym. Głównym wrogiem stały się Stany Zjednoczone, które przedstawiano jako źródło wszelkich działań przeciwko ZSRR i państwom Układu Warszawskiego ${ }^{59}$. Ukazując ZSRR korzystano z tych samych narzędzi, które służyły wskazaniu w okresie międzywojennym wrogów komunizmu, a później członków Trójprzymierza. Negatywny bohater był brzydki, gruby, z workami pieniędzy dzięki którym przekupywano wszystkich polityków i wszelkie organizacje międzynarodowe mające być niezależnymi. W oficjalnym obiegu nie istniały karykatury niezgodne z oficjalną polityką państwa lub krytykujące państw. Możliwe były jedynie karykatury ukazujące drobne niedociągnięcia konkretnych urzędników i osób, wobec których państwo podjęło odpowiednie działania ${ }^{60}$.

Dopiero w drugiej połowie lat osiemdziesiątych, gdy oficjalnie ogłoszono politykę ,głasności”, która pozwoliła na otwarte wypowiadanie własnych poglądów, stała się możliwa krytyka władzy oraz wykorzystywanie do tego celu karykatury. Satyrę postrzegano wówczas jako instrument przepływu informacji między spo-

${ }^{58}$ Zob. szerzej w tym temacie M. Bryant, II wojna światowa w karykaturze, Warszawa 2012, passim; Карикатура, как орудие пропаганды в суровые годы Великой Отечественной войны, http://garhivelg.su/index.php/exhibitions/cartoon/ [dostęp: 05.10.2017].

59 А.В. Фатеев, Образ врага в советской пропаганде, 1945-1954, Moskwa 1999, passim; Е.А. Федосов, Внешний мир глазами советской пропаганды 1950-х начала 1960-х г2. В плакатах и карикатурах, „Вестник Томского государственного университета. История”, 2013, nr 1 (21), s.106-109.

${ }^{60}$ Zob. Szerzej A. Кротков, Карикатура. Непридуманная история, Moskwa 2015, http://bit. ly/2zfguLS [dostęp: 05.10.2017]; А. В. Дмитриев, Социология политического юмора: Очерки, Moskwa, 1998. С. 74-100; Борис Ефимов в «Известиях»: Карикатуры за полвека, Moskwa 1969, s. 80; J. Ślęzak-Gotkowska, Stosunki międzynarodowe okresu zimnej wojny w karykaturze polskiej na przykładzie czasopism satyrycznych ,Mucha”, ,Karuzela”, ,, Szpilki”, http://repozytorium.ur.edu.pl/handle/item/1902 [dostęp: 05.10.2017]. 
łeczeństwem i władzą. W Związku Radzieckim skupiono się w związku z tym w karykaturze na ocenie sytuacji wewnętrznej, pozwalając na niepochlebne ukazywanie nawet najwyższych urzędników państwowych ${ }^{61}$. W Polsce natomiast także nastąpiło stopniowe zmniejszenie obecności polityki państwowej w prasie, a po przemianie systemowej w 1989 r. rynek prasowy zaczął się rządzić zasadami gospodarki wolnorynkowej, co zmieniło charakter karykatury, która przestała być jednym z instrumentów propagandy państwowej, choć nadal służyła partykularnym interesom grup wpływu, ale głównie wyrażaniu nastrojów społecznych.

\section{CARICATURE AS A TOOL OF STATE POLICY}

\section{Summary}

Satire in all countries is protected as a manifestation of public mood and for this reason it is not subject to criminal liability. Caricature is a specific kind of satirical art. During an analysis of the history of the USSR and Poland, one can highlight the special role of caricature in the implementation of a state's international policy. It served as an instrument of reaching the least educated social strata with state propaganda. It is also worth noting that caricature played a smaller or a larger part for the state at different periods of history.

\section{CARICATURE EN TANT QU'OUTIL DE LA POLITIQUE D’ÉTAT}

\section{Résumé}

Dans tous les pays, la satire est protégée comme une manifestation du sentiment social, et c'est pourquoi elle n'est pas soumise à la responsabilité pénale. La caricature est une forme spécifique d'art satirique. En analysant l'histoire de l'URSS et de la Pologne, il est bon d'attirer l'attention sur le rôle particulier de la caricature dans la mise en œuvre de la politique étrangère de l'État. Elle a servi d'instrument pour faire la propagande d'État auprès des milieux sociaux les moins éduqués. À diverses étapes de l'histoire, la caricature jouait un rôle plus ou moins grand pour l'État.

${ }^{61}$ Zob. Е.В. Середина, Роль синтаксических средств в политической карикатуре, „Научный журнал КубГАУ”, 2013, nr 91, s. 1780-1789. 
